Pesq. Vet. Bras. 38(1):137-142, janeiro 2018 DOI: $10.1590 / \mathrm{S} 0100-736 \mathrm{X} 2018000100022$

\title{
Detection of bluetongue virus in Brazilian cervids in São Paulo state ${ }^{1}$
}

\author{
Aline E. Kawanami ${ }^{2 *}$, Juliana P. de Oliveira² ${ }^{2}$ Alexandre Arenales ${ }^{2}$, Beate \\ Crossley $^{3}$, Leslie W. Woods ${ }^{3}$, José M.B. Duarte ${ }^{2}$ and Karin Werther ${ }^{2}$
}

\begin{abstract}
Kawanami A.E., Oliveira J.P., Arenales A., Crossley B., Woods L.W., Duarte J.M.B. \& Werther K. 2018. Detection of bluetongue virus in Brazilian cervids in São Paulo state. Pesquisa Veterinária Brasileira 38(1):137-142. Departamento de Patologia Veterinária, Universidade Estadual Paulista "Júlio de Mesquita Filho", Faculdade de Ciências Agrárias e Veterinárias, Via de acesso Prof. Paulo Donato Castellane, Jaboticabal, SP 14884-900, Brazil. E-mail: aline.kawanami@gmail.com

Viral hemorrhagic diseases in cervids occur worldwide and include epizootic hemorrhagic disease (EHD), bluetongue (BT), and adenoviral hemorrhagic disease (AHD). Since gross lesions in all three hemorrhagic diseases are identical (hemorrhagic enteropathy, pulmonary edema, systemic petechial and suffusion hemorrhages), it is necessary to use accurate techniques for a definitive etiologic diagnosis. Archival material (paraffin blocks) at the Department of Veterinary Pathology of FCAV - Unesp was reviewed for lesions of hemorrhagic disease and 42 captive and free-living Brazilian deer were selected to include in this study. Paraffin-embedded tissues were evaluated using immunohistochemistry and tested negative for adenovirus. Using real time RT-PCR, EHD virus was not detected in paraffin-embedded tissues in any of the cases evaluated. The same technique was used for detection of BT virus and seven positive animals $(16,66 \%)$ were confirmed after agarose $4 \%$ gel electrophoresis and gene sequencing. The main macroscopic changes observed in the positive animals were hemorrhagic intestinal contents, reddish mucous membrane of the gastrointestinal tract, ulcers on tongue and petechiae in various organs. Microscopic changes observed were lymphocytic inflammatory infiltrate in liver, kidney and lungs, hemorrhage, and congestion in various organs. All positive cases were from captive animals, three females (two young and one adult), and four young males. This study demonstrates that the bluetongue virus is involved in hemorrhagic disease outbreaks of deer in Brazil.
\end{abstract}

INDEX TERMS: Adenoviral hemorrhagic disease, Brazilian cervids, epizootic hemorrhagic disease, bluetongue, hemorrhagic diseases, viroses.

RESUMO.- [Detecção de vírus da língua azul em cervídeos brasileiros no estado de São Paulo.] Doenças hemorrágicas virais em cervídeos ocorrem no mundo todo e incluem a doença epizoótica hemorrágica (DEH), língua azul (LA), e doença hemorrágica por adenovírus (DHA). Uma vez que as lesões nas três doenças hemorrágicas são idênticas (enteropatia hemorrágica, edema pulmonar, petéquias

\footnotetext{
${ }^{1}$ Received on January 19, 2016.

Accepted for publication October 10, 2016.

${ }^{2}$ Faculdade de Ciências Agrárias e Veterinárias (FCAV), Universidade Estadual Paulista "Júlio de Mesquita Filho" (Unesp), Via de acesso Prof. Paulo Donato Castellane, Jaboticabal, SP 14884-900, Brazil. *Corresponding author: aline.kawanami@gmail.com

${ }^{3}$ California Animal Health and Food Safety Laboratory (CAHFS), University of California (UC), One Shields Avenue, Davis, California 95616, USA.
}

sistêmicas e sufusões hemorrágicas), é necessário utilizar técnicas precisas para um diagnóstico etiológico definitivo. Material de arquivo (blocos de parafina) do Departamento de Patologia Veterinária da FCAV - Unesp foi revisado para lesões de doenças hemorrágicas e 42 cervídeos brasileiros de cativeiro e de vida livre foram selecionados e incluídos neste estudo. Tecidos embebidos em parafina foram avaliados usando imunohistoquímica e foram negativos para adenovírus. Usando o RT-PCR em tempo real, o vírus da DEH não foi detectado nos tecidos de nenhum dos casos avaliados. A mesma técnica foi utilizada para detecção do vírus da LA e sete animais positivos (16,66\%) foram confirmados após eletroforese em gel de agarose a $4 \%$ e sequenciamento genético. As principais alterações macroscópicas observadas nos animais positivos foram conteúdo intesti- 
nal hemorrágico, mucosa do trato gastrointestinal avermelhada, úlceras na língua e petéquias em vários órgãos. As alterações microscópicas observadas foram infiltrado inflamatório linfocítico em fígado, rins e pulmões, e hemorragia e congestão em vários órgãos. Todos os casos positivos foram de animais de cativeiro, três fêmeas (dois jovens e um adulto), e quatro jovens do sexo masculino. Este estudo demonstra que o vírus da lingual azul está envolvido nos surtos de doença hemorrágica em veados no Brasil.

TERMOS DE INDEXAÇÃO: Doença hemorrágica por adenovírus, cervídeos brasileiros, doença epizoótica hemorrágica, língua azul, doenças hemorrágicas, viroses.

\section{INTRODUCTION}

In Brazil, there are eight species of deer, three of which have vulnerable conservation status (IUCN 2016). Diseases introduced by cattle have been a major cause of death, including numerous viral, bacterial and parasitic diseases of cattle that can affect deer (Pinder \& Leeuwenberg 1997).

Hemorrhagic diseases have been important causes of mortality in captive deer in Brazil. Several herds have been affected by hemorrhagic disorders of unknown etiology. Reports of up to $40 \%$ morbidity and with high mortality have been reported, where these outbreaks typically had a seasonal occurrence, primarily occurring in humid and warm seasons (Arita et al. 1997). After the first description of the disease affecting Brazilian cervids in the Research and Conservation Center of Cervids - NUPECCE (Duarte \& Arita 1992) it was also reported in zoos and other captive facilities (Morato et al. 1993).

Hemorrhagic diseases that occur in cervids include adenovirus hemorrhagic disease (AHD); bluetongue (BT) and epizootic hemorrhagic disease (EHD), the latter two caused by orbiviruses. Previous serologic surveillance studies with agar gel immunodiffusion test (AGID) for BT virus and EHD virus in Brazilian livestock and wild ruminants have demonstrated the presence of antibodies (Pandolfi 1999, Melo et al. 2000, Alves et al. 2009, Mota et al. 2011). There are no reports about occurrence of adenovirus hemorrhagic disease in deer in Brazil.

Since deer with EHD, BT and AHD show similar clinical signs and lesions (Woods et al. 1996), the use of other laboratory techniques is necessary to elucidate the etiology of these infectious processes, such as immunohistochemical, transmission electron microscopy and/or detection of genetic material, such as the polymerase chain reaction (PCR).

Since 1994 deer necropsies have been conducted in the Department of Veterinary Pathology, FCAV - Unesp. Frequently necropsied deer had macro- and microscopic lesions suggestive of viral hemorrhagic disease, but etiology was not determined. Thus, the aim of this retrospective study was to detect the virus of AHD, EHD and BT in tissue samples fixed in formalin and embedded in paraffin from deer with clinical signs and/or lesions suggestive of hemorrhagic diseases.

\section{MATERIALS AND METHODS}

Ethics statement. For this study, paraffin embedded samples from deer necropsied between the years 1994-2011 in the De- partment of Veterinary Pathology, FCAV - Unesp were used. The research was approved by the Ethics Committee on Animal Use of this institution (protocol \#009908/11) and the Chico Mendes Institute for Biodiversity Conservation (authorization \#26519-1). The animals originated from Brazil, from captive (zoos, research center or conservation center) and free-living fauna (referred by Fire Department, the Environmental Police and highway concessionaires). From a total of 253 deer necropsied, 42 cases were selected in which the animals had clinical signs and gross lesions suggestive of hemorrhagic disease. Of the 42 deer studied, of both sexes and of different ages, coming from free-living or captive, 17 were Marsh Deer (Blastocerus dichotomus), 12 Gray Brocket Deer (Mazama gouazoubira), eight Red Brocket Deer (Mazama americana), three Pygmy Brocket Deer (Mazama nana), one Small Red Brocket Deer (Mazama bororo) and one Amazonian Brown Brocket Deer (Mazama nemorivaga).

Necropsy. Deer were necropsied and select tissues (liver, spleen, lung, and kidney) were collected and fixed in 10\% formalin buffered. Fixation times ranged from a few days to five months. Formalin-fixed tissues were embedded in paraffin and $5 \mu \mathrm{m}$ sections were stained in hematoxylin-eosin and read by light microscopy. All these steps were performed at the Pathology Laboratory, Department of Veterinary Pathology, FCAV - Unesp, Jaboticabal.

Imunohistochemistry (IHC). To study the presence of adenovirus was used IHC, performed in "California Animal Health and Food Safety Laboratory" (CAHFS) at the University of California, Davis. From the paraffin-embedded tissues, two $4 \mu \mathrm{m}$ sections were made from each block, one for specific antibody and one for non-specific antibody (negative control). The specific antibody was polyclonal rabbit anti-adenovirus; made by Dr. Howard D. Lehmkuhl's laboratory (U.S. Department of Agriculture, Agricultural Research Service, National Animal Disease Center, Ames, Iowa, USA) that cross react with deer adenovirus. The deparaffinization and hydration were performed using battery of xylene and alcohol in decreasing concentrations. Then, the slides were incubated in $0.5 \%$ pepsin at $37^{\circ} \mathrm{C}$ for 10 minutes to recover the antigen. The slides were then washed in water and Tween-Tris buffered saline, plus $200 \mu \mathrm{L}$ of polyclonal rabbit anti-adenovirus at a dilution of 1:1500. The slides of negative control were placed 200 $\mu \mathrm{L}$ of non-specific antibody - rabbit IgG at a dilution 1:1500. Both slides with specific primary antibodies and non-specific were for 30 minutes at room temperature, and then washed with buffer solution.

In the next step, all the slides received $400 \mu \mathrm{L}$ of secondary antibody: biotinylated antibody goat anti-rabbit (Vector Labs ${ }^{\circledR}$ ) diluted 1:200 and incubated for 30 minutes. After washing with buffer solution, was added $400 \mu \mathrm{L}$ of conjugate solution (Horseradish peroxidase-labeled Streptoavidin, Lab ${ }^{\circledR}$ Jackson) diluted 1:1000. After 30 minutes at room temperature, the slides were washed with buffer. Then was added $400 \mu \mathrm{L}$ of chromogen 3-amino-9-ethylcarbazole (AEC, DakoCytomation ${ }^{\circledR}$ ) on the slides and after 10 minutes were again washed with buffer solution. The slides were then placed in vats containing Mayer's hematoxylin $\left(\right.$ Sigma $\left.{ }^{\circledR}\right)$, where they remained for seven minutes and then were washed in running water. The slides were immersed for 2 minutes in running water. The last step was to cover the slides with aqueous mounting, allow to dry for 30 minutes and then cover them with means of synthetic mounting media and cover slip to later be read by light microscopy.

In addition to the manual process of IHC described above, half of the material (21 samples) was processed in automated equipment "Immuno Autostainer" (DAKO $\left.{ }^{\circledR}\right)$. The only steps that were done manually in the material after processing "Immuno Autostainer" were immersion in Mayer's hematoxylin, and covered with 
aqueous mounting media, synthetic mounting media and cover slip.

Polymerase chain reaction in real time preceded by reverse transcription. To investigate the presence of Bluetongue virus (BTV) and Epizootic hemorrhagic disease virus (EHDV), the method used was RT-PCR in real time, including the steps of extraction of RNA, real time RT-PCR, electrophoresis on agarose gel and sequencing. All procedures were carried out and completed at the "California Animal Health and Food Safety Laboratory" (CAHFS) at the University of California, Davis.

From each block of paraffin-embedded tissues, four $20 \mu \mathrm{m}$ sections were made and were placed in $1.5 \mathrm{~mL}$ microfuge tubes. To avoid contamination between materials, microtome knives were changed after each block cut. The deparaffinization process of tissues and RNA extraction were performed using the "RECOVERALL $^{\mathrm{TM}}$ Total Nucleic Acid Isolation Kit” (Life Technology ${ }^{\circledR}$ ), following the manufacturer's instruction manual.

After extraction the RNA was converted into cDNA and performed RT-PCR in real time using the kits SuperScript ${ }^{\circledR}$ III One-Step RT-PCR System with Platinum Taq DNA Polymerase (Life Technologies) and Path-IDTM Multiplex One-Step RT-PCR kit (Applied Biosystems ${ }^{\circledR}$ ) to BTV and EHDV, respectively, according to recommendations of the manufacturer. The thermocycler used was Cepheid SmartCycler 2d version (Sunnyvale, CA) to perform the RT-PCR in real time for the BTV. For EHDV the thermocycler used was Applied Biosystems 7500 Fast Platform (Carlsbad, CA).

The reactions were carried out to BTV essentially as previously described by Orru et al. (2006), with the modifications suggested by Hofmann et al. (2008). For EHDV the primer and probe information was kindly provided by Dr K. Kurth (WVDL, Madison, WI). The target gene that was amplified was NS3 gene (segment 10) for BTV and NS1 gene for EHDV. In each reaction negative and positive extraction as well as PCR controls were utilized. Reaction conditions for BTV were one cycle of 30 minutes at $48^{\circ} \mathrm{C}$ for cDNA synthesis, a two minute cycle at $95^{\circ} \mathrm{C}$ for initial denaturation plus 50 cycles of $95^{\circ} \mathrm{C}$ and 15 seconds, $56^{\circ} \mathrm{C}$ for 30 seconds and $72^{\circ} \mathrm{C}$ for 30 seconds. The reaction conditions for EHDV were a $10 \mathrm{mi}-$ nute cycle at $50^{\circ} \mathrm{C}$ for cDNA synthesis, a 10 -minute cycle at $95^{\circ} \mathrm{C}$ for initial denaturation, 40 cycles of $95^{\circ} \mathrm{C}$ for 15 seconds and $60^{\circ} \mathrm{C}$ for 1 minute.

Agarose gel electrophoresis and sequencing. The materials subjected to RT-PCR in real time also underwent further analysis, agarose gel electrophoresis, to confirm the presence of the amplicon specific bands of the expected sizes. Amplified PCR products were subjected onto $4 \%$ agarose gel at 210 volts for 27 minutes. The marker used was "All Purpose Hi-Lo DNA Marker" (Bionexus ${ }^{\circledR}$ Inc., Oakland, CA) and amplified fragments were visualized with ultraviolet light. RT-PCR products were purified and subjected to private sequencing facility.

\section{RESULTS AND DISCUSSION}

In the early 90 's the first reports of deer with clinical signs and lesions suggestive of hemorrhagic disorders, such as BT and EHD, were published in Brazil but without the identification of the etiological agent (Duarte \& Arita 1992, Morato et al. 1993, Arita et al. 1997). Cervids with AHD have similar lesions (Woods et al. 1996). Therefore, this study was designed to elucidate the primary cause of hemorrhagic diseases in deer in Brazil using detection methods for BTV, EHDV and ADHV.

The main clinical signs from selected animals were: appetite loss in $35.71 \%(\mathrm{n}=15)$, lethargy $28.57 \%(\mathrm{n}=12)$ and lesions on the tongue/mouth in $28.57 \%(n=12)$. Other important signs such as diarrhea/soft feces $(21.43 \%, \mathrm{n}=9)$, emaciation $(19.05 \%, \mathrm{n}=8)$, drooling $(19.05 \%, \mathrm{n}=8)$ and edema in the head $(16,67 \%, n=7)$ were also observed. The clinical signs of animals selected for this study were consistent with those found in animals diagnosed with viral hemorrhagic disease (Stott 1999, Murphy et al. 1999, Woods et al. 2001).

The most relevant macroscopic findings observed in necropsies were: hemorrhagic intestinal contents in $71.43 \%$ $(\mathrm{n}=30)$, petechiae in organs $(47.62 \%, \mathrm{n}=20)$ such as heart (endocardium), tongue and stomachs, reddish gastrointestinal mucosa $(33.33 \%, \mathrm{n}=14)$ and necrosis/ulceration in the mouth/tongue in $26.19 \%(\mathrm{n}=11)$, consistent with those cited in literature (Woods et al. 1999, MacLachlan, 2011).

In this study, the 42 Brazilian deer analyzed by immunohistochemistry for the agent of AHD, were negative. The negative results for AHD could be due to the fixing process of the samples. Depending on the length that the sample stays in formalin, structural changes can occur in the agent, hindering standardization and efficiency of immunohistochemistry (Shi et al. 2005). Another hypothesis is that the tested animals are actually negative due to absence of the agent or resistance of Brazilian deers species to disease. The disease was first diagnosed in cervids in the United States (California, Oregon and Iowa) and Canada (Ontario) causing high mortality rates (Woods et al. 1996, Sorden et al. 2000, Shilton et al. 2002). It is a viral disease described by Woods et al. (1996), and the epidemiology and pathogenesis have not been fully elucidated.

Due to high mortality and lack of treatment options, it is important to prevent the introduction of adenovirus in deer in Brazil. To reduce the risk of introduction of the virus, it is recommended not to mix free living animals with animals in captivity, although apparently healthy. Captive animals with a history of adenovirus infection should not be transferred or released into the wild, since they can serve as carriers of the virus (Boyce et al. 2000). Indirect sources of contamination must be considered, because adenoviruses are stable in the environment (Murphy et al. 1999). Thus, it is important that there is epidemiological surveillance and close monitoring to prevent asymptomatic, adenovirus-infected deer from introducing the disease to Brazil free-ranging deer.

In North America, the legalized hunting facilitated access to biological material (samples from animals shot by hunters) for epidemiological research in the free ranging population. In Brazil, the distribution of species in their different habitats and the size of the country make the effective monitoring of animals and their diseases difficult. Because ADHV is a relatively new disease, research diagnosis of the ADHV in Brazil had not yet been carried out, valuing the work presented here.

The other viral hemorrhagic diseases in this study were the orbiviruses, BTV and the EHDV. They are infectious but noncontagious arthropod-borne viral diseases of domesticated and wild ruminants (Frölich et al. 2005).

EHD virus was not detected by RT-PCR in any of the samples that were tested. EHD causes serious disease in wild ruminants. The severity of the lesions varies accor- 
ding to the species affected. In North America, Black-tailed Deer (Odocoileus hemionus), Pronghorn Antelope (Antilocapra americana), Hart-noble (Cervus elaphus) and Whitetailed Deer (Odocoileus virginianus) are species susceptible to infection with the EHD, the latter one most sensitive to severe fatal infection (Brodie et al. 1998). In Brazil, the first isolation of EHDV in deer was from a Pygmy Brocket Deer (Mazama nana) that died in a Zoo in Santa Catarina state (Favero et al. 2013). One possible explanation for the negative results is EHDV was not the cause of the hemorrhagic disease in any of the deer tested. However, serological studies in 107 free living Marsh Deer showed a high prevalence $(71 \%)$ of animals with antibodies to EHDV (Montassier et al. 2001). Most animals of this study were from the NUPECCE which is where Pandolfi (1999) described 9\% EHDV seropositive animals in a herd of 22.

Another explanation for the negative results could be formalin fixation time, ranging from several days to five months. The fixation process alters the RNA by adding methylol group $(-\mathrm{CH} 2 \mathrm{OH})$ at the nucleotide (Massuda et al. 1999). Mckinney et al. (2009) demonstrated that it is possible to extract and amplify RNA from fixed tissues remained in formalin for a period of 21 and 30 days. The paraffin blocks filing time is also a factor that can interfere with the integrity of genomic material, since degradation by endogenous RNase and RNA fragmentation continue to happen even after the tissue is dehydrated and embedded in paraffin, which can interfere in the reverse transcription of RNA and reduce the efficiency of the PCR (Massuda et al. 1999, Ribeiro-Silva et al. 2007). The filing time of the paraffin blocks used in this study ranged from one to 18 years and may have affected the results obtained.

For detection of BTV initially using RT-PCR, three samples were positive (7.14\%) and four (9.52\%) showed high Cycle threshold $(\mathrm{Ct})$ values suggesting a low virus concentration. To confirm the results of this technique, all samples were also submitted to electrophoresis on $4 \%$ agarose gel, where it was found seven samples $(16.66 \%)$ positive for the BTV.

Positive bands on $4 \%$ agarose gel from the seven samples were purified and sequenced. Sequences were blasted against other sequences in the NCBI data base, revealing highest similarity with other BTV sequences. These are the same samples detected by RT-PCR. The seven positive animals tested for BTV were from captive herds, two B. dichotomus from the CCCP (Center for Conservation of the Mash deer)/CESP (Companhia Energética de São Paulo, Promissão - SP) and five deer (two B. dichotomus, two M. gouazoubira and one M. americana) were from the herd of NUPECCE (Center for Research and Conservation of Cervids, UNESP, Jaboticabal - SP). Six affected animals were young (85.71\%) and one was an adult (14.29\%). Sex distribution was three females (42.86\%) and four males (57.14\%).

Bluetongue exists in an extensive band that includes tropical, subtropical, and temperate regions of the world between latitudes of approximately $40^{\circ}$ North and $35^{\circ} \mathrm{Sou}-$ th (MacLachlan 2011). Hematophagous Culicoides insect vectors that transmit BTV from infected to susceptible ruminants, thus the global distribution of BTV coincides with the distribution of competent Culicoides insect vectors and appropriate climatic conditions (MacLachlan 2011).

Clinical signs observed in these seven positive animals ranged from no clinical signs, non-specific signs such as anorexia/decreased appetite and, lethargy and hemorrhagic disease signs such as diarrhea and submandibular edema, observed in one animal, and drooling and tongue lesions, observed in two animals.

The main gross lesions in the seven positive animals were hemorrhagic intestinal contents $(85.71 \%, \mathrm{n}=6)$, petechiae $(57.14 \%, \mathrm{n}=4)$ in tongue and heart, red mucous membranes of the gastrointestinal tract $(42.86 \% \mathrm{n}=3)$ and tongue ulcers $(42.86 \%, \mathrm{n}=2)$.

Histopathological changes in the positive animals for BTV were lymphocytic inflammatory infiltrate in various organs, including, kidney, liver and lung; hemorrhage $(71.43 \%, \mathrm{n}=5)$ in the heart, kidney, trachea, muscle and rumen, and congestion $(71.43 \%, \mathrm{n}=5)$ in lung, kidney, liver and trachea. Kidney artery thrombus was found in one animal. The primary lesions are associated with vascular damage caused by viral replication (Osburn 2007), increasing vascular permeability, favoring edema in tissues, especially the lung, and thrombus formation with subsequent infarctions (MacLachlan 2004).

Six of the positive cervids were young $(85.7 \%)$ with ages between 8 months to 1 year and 8 months old and one was an adult (14.3\%) with 14 years old, suggesting that younger animals are more susceptible to disease (although more numbers are needed to even make a correlation statement). According to the study of Gaydos et al. (2002), maternal antibodies to EHD and BT viruses in White-tailed Deer remained for up to about 6 months of age (or 23 weeks old) and neutralizing antibodies for about 4 months old (17-18 weeks of age), what could explain why deer over 8 months of age appear to be more susceptible to hemorrhagic diseases in the present study. Regarding gender (three females and four males) and the affected species could not suggest a correlation for the occurrence of the disease.

All positive animals were from captivity; five from the NUPECCE. A serologic study of animals in the same region was performed in 1998-1999 using the competitive ELISA which demonstrated the presence of antibodies to BTV in $23 \%$ for a total of 22 deer tested (Pandolfi 1999). Antibody detection and proof of agent presence in NUPECCE animals show that the herd had contact with the virus; the animals are susceptible and infected with BTV. Duarte (2007) states that the hemorrhagic disease outbreaks occurred in cervids, and affected NUPECCE for several years with an annual loss of about $50 \%$ of the herd. In some years, $90 \%$ of the animals developed hemorrhagic disease and died. The control of the disease was done with the use of screens in the sheds and ectoparasiticides every 15 days during the spring and summer.

Cattle infected with BTV are usually asymptomatic and have long viremia period, serving as reservoirs, infecting the vectors that transmit the virus to deer. In cattle, the virus is detected in the blood for 35 to 60 days post-infection, lasting for up to 160 days (Katz et al. 1994). Serological studies for BTV performed in Brazil in domestic ruminants 
(cattle, sheep, goats, and buffaloes) indicate that the infection is widely distributed in all regions, including the Paraíba (Melo et al. 2000, Alves et al. 2009), Pernambuco (Mota et al. 2011), Bahia (Souza et al. 2010), Minas Gerais (Castro et al. 1992, Lage et al. 1996, Konrad et al. 2003), Sao Paulo (Nogueira et al. 2009, Venditti 2009), Rio Grande do Sul (Costa et al. 2006) and Mato Grosso do Sul (Pellegrin et al. 1997). In a serological study of domestic ruminants living near NUPECCE, antibodies for BTV were detected mainly in cattle $(97 \%, n=73)$ and sheep $(87 \%, n=54)$ (Pandolfi 1999), suggesting that these animals could be source of infection for the affected deer in NUPECCE.

Considering that much of the South America is located in an endemic area for the occurrence of both BT and EHD, it is expected that clinical disease is rarely observed. Moreover, considering the great variability of clinical signs and the larger number of other endemic diseases that have the similar clinical aspect, it is possible to assume that clinical cases are underreported (Lobato et al. 2015). Many gaps related to the information about the orbiviruses vectors in South America exist; BTV and EHDV have never been isolated from any vector in this continent (Lobato et al. 2015). Further studies with Culicoides mosquitoes, including the ability and competence of the vector and also serotypes occurring in domestic and wild ruminants should be considered.

The negative results for BTV can be explained by the same technical reasons discussed previously for EHDV detection (fixing time and archiving of blocks). However, in this study, the samples positive for BTV were fixed in formalin for a period ranging from six to 45 days and the filing time of the paraffin blocks that originated this research was three to 15 years, not interfering with the positivity of samples.

New serotypes of BTV were isolated and identified from outbreaks affecting Pygmy Brocket Deer in a Zoo in Foz do Iguaçu, Paraná. The new serotypes of BTV identified were serotype $3,14,18,19$ and 22 and was the cause of the death of the animals (OIE 2016). The sequencing and identification of BTV serotypes of this work have been compromised due to fragmentation of genomic material, possibly due to the sample age and the fixation in formalin.

Considering the clinical signs and gross lesions presented by the animals in this study and taking into account the negative results for the three surveyed viral diseases in some animals, differential diagnosis of other diseases, such as foot and mouth disease, malignant catarrhal fever, bovine viral diarrhea, rotavirus and coronavirus should be considered (Haigh et al. 2002, Williamson et al. 2008).

\section{CONCLUSIONS}

Brazilian deer with hemorrhagic disease are primarily infected with BTV.

Although some tissue samples were stored in formalin for 45 days, it was possible to detect BTV genomic material by real time RT-PCR.

The time of filing of paraffin blocks was up to 15 years and therefore time tissue was embedded in paraffin did not interfere with the detection of BTV genomic material by real time RT-PCR under the conditions of some of the samples tested in this study.

Studies in Brazil with virus agents of hemorrhagic disease in domestic and wild ruminants are scarce, making it difficult to rank the country in relation to these diseases. The identification of serotypes of the orbiviruses that occur in Brazil is essential to develop and implement programs with appropriate measures for the control of the diseases. Molecular and serological studies integrated into entomological studies must be conducted in domestic and wild ruminants, not only in Brazil but in South America in order to assess the current situation of viruses in populations of these animals and the impacts that they can cause.

Acknowledgements.- The authors wish to thank São Paulo Research Foundation (FAPESP) who generously funded by grant 2010/14787-4, the laboratory technicians from California Animal Health and Food Safety, UC Davis and from Faculty of Agricultural and Veterinary Sciences, Veterinary Pathology Department, Univ Estadual Paulista for their expert work in processing the samples.

Conflict of interest statement.- The authors have no competing interests.

\section{REFERENCES}

Alves F.A.L., Alves C.J., Azevedo S.S., Silva W.W., Silva M.L.C.R., Lobato Z.I.P. \& Clementino I.J. 2009. Seroprevalence and risk factors for Bluetongue in rams of the Sertão and Borborema mesoregions, semi-arid of Paraíba state, Northeastern Brazil. Ciência Rural 39:484-489.

Arita G.M.M., Morato R.G. \& Duarte J.M.B. 1997. Língua azul e/ou doença epizoótica hemorrágica. In: Duarte J.M.B. (Ed.), Biologia e Conservação dos Cervídeos SulAmericanos: Blastocerus, Ozotoceros e Mazama. Funep, Jaboticabal. 238p.

Boyce W.M., Woods L.W., Keel M.K., MacLachlan N.J., Porter C.O. \& Lehmkuhl H.D. 2000. An epizootic of adenovirus-induced hemorrhagic disease in captive black-tailed deer (Odocoileus hemionus). J. Zoo Wildl. Med. 31:370-373.

Brodie S.J., Bardsley K.D., Diem J., Mecham J.O., Norelius S.E. \& Wilson W.C. 1998. Epizootic hemorrhagic disease: analysis of tissues by amplification and in situ hybridization reveals widespread orbivírus infection at low copy numbers. J. Virology 72:3863-3871.

Castro R.S., Leite R.C., Abreu J.J., Lage A.P., Ferraz I.B., Lobato Z.I.P. \& Balsamo S.L. 1992. Prevalence of antibodies to selected viruses in bovine embryo donors and recipients from Brazil, and its implications in international embryo trade. Tropic. Anim. Health Prod. 24:173-176.

Costa J.R.R., Lobato Z.I.P., Herrmann G.P., Leite R.C. \& Haddad J.A.P. 2006. Bluetongue virus antibodies in cattle and sheep in Southwest and Southeast regions of Rio Grande do Sul, Brazil. Arq. Bras. Med. Vet. Zootec. 58:273-275.

Duarte J.M.B. 2007. Artiodactyla - Cervidae (veado-catingueiro, veado-campeiro, cervo-do-pantanal), p.641-664. In: Cubas Z.S., Silvas J.C.R., Catão-Dias J.L. (Eds), Tratado de Animais Selvagens. Roca, São Paulo, Brazil.

Duarte J.M.B. \& Arita G.M.M. 1992. Ocorrência de doença hemorrágica em um plantel de Mazama gouazoubira (veado catingueiro), possivelmente causado pelo vírus da língua azul e orbivírus relacionados. Anais XLVII Conferência Anual da Sociedade Paulista de Medicina Veterinária e 1ํㅡ Encontro Nacional da ABRAVAS, São Paulo, Brazil.

Favero C.M., Matos A.C.D., Campos F.S., Cândido M.V., Costa E.A., Heinemann M.B., Barbosa-Stancioli E.F. \& Lobato Z.I.P. 2013. Epizootic hemorrhagic disease in brocket deer, Brazil. Emerg. Infect. Dis. 19(2):346-348.

Frölich K., Hamblin C., Jung S., Ostrowski S., Mwanzia J., Streich W.J., Anderson J., Armstrong R.M. \& Anajatiyah S. 2005. Serologic surveillance for selected viral agents in captive and free-ranging populations of Arabian oryx (Oryx leucoryx) from Saudi Arabia and The United Arab Emirates. J. Wildl. Dis. 41(1):67-79. 
Gaydos J.K., Stallknecht D.E., Kavanaugh D., Olson R.J. \& Fuchs E.R. 2002. Dynamics of maternal antibodies to hemorrhagic disease viruses (Reoviridae: Orbivirus) in White-tailed deer. J. Wildl. Dis. 38(2):253-257.

Haigh J.C., Mackintosh C. \& Griffin F. 2002. Viral, parasitic and prion diseases of farmed deer and bison. Revue Scientifique et Technique, Office International des Epizooties 21:219-248.

Hofmann M.A., Renzullo S., Chaignat V., Worwa G. \& Thuer B. 2008. Genetic characterization of toggenburg orbivírus, a new bluetongue virus, from goats, Switzerland. Emerg. Infect. Dis. 14:1855-1861.

IUCN 2016. The IUCN Red List of Threatened Species. Version 2016-1 <www.iucnredlist.org> Downloaded on 14 July 2016.

Katz J., Alstad D., Gustafson G. \& Evermann J. 1994. Diagnostic analysis of the prolonged bluetongue virus RNA presence found in blood of naturally infected cattle and experimentally infected sheep. J. Vet. Diagn. Invest. 6:139-142.

Konrad P.A., Rodrigues R.O., Chagas A.C.P., Paz G.F. \& Leite R.C. 2003. Antibodies against the blue tongue virus in dairy cattle in the state of Minas Gerais, Brazil and associations with reproductive problems. Revta Fac. Zootec. Vet. Agron., Uruguaiana, 10:42-51.

Lage A.P., Castro R.S., Melo M.I., Aguiar P.H., Barreto Filho J.B. \& Leite R.C. 1996. Prevalence of antibodies to bluetongue, bovine herpesvirus 1 and bovine viral diarrhea/mucosal disease viruses in water buffaloes in Minas Gerais state, Brazil. Revue d'Élevage et de Médecine Vétérinaire des Pays Tropicaux 49:195-197.

Lobato Z.I.P., Guedes M.I.M.C. \& Matos A.C.D. 2015. Bluetongue and other orbiviruses in South America: gaps and challenges. Veterinaria Italiana 51(4):253-262.

MacLachlan N.J. 2004. Bluetongue: pathogenesis and duration of viraemia. Veterinaria Italiana 40:462-467.

MacLachlan N.J. 2011. Bluetongue: history, global epidemiology, and pathogenesis. Prev. Vet. Med. 102:107-111.

Massuda N., Ohnishi T., Kawamoto S., Mondem M. \& Okubo K.1999. Analysis of chemical modification of RNA from formalin-fixed samples and optimization of molecular biology applications for such samples. Nucleic Acids Research 27:4436-4443.

Mckinney M.D., Moon S.J., Kulesh D.A., Larsen T. \& Schoepp R.J. 2009. Detection of viral RNA from paraffin-embedded tissues after prolonged formalin fixation. J. Clin. Virol. 44:39-42.

Melo C.B., Oliveira A.M., Azevedo E.O., Lobato Z.I.P. \& Leite R.C. 2000. Antibodies to bluetongue virus in bovines of Paraíba State, Brazil. Arq. Bras. Med. Vet. Zootec. 52(1).

Montassier H.J., Pandolfi J.R., Araújo Jr. J.P. \& Duarte J.M.B. 2001. Língua Azul (LA) e Doença Hemorrágica Epizoótica dos Cervídeos (DHEC) em Cervos-do-Pantanal (Blastocerus dichotomus). Estudo sorológico e identificação viral. In: Duarte, J.M.B. O Cervo-do-Pantanal (Blastocerus dichotomus) de Porto Primavera: resultado de dois anos de pesquisa. (CD-ROM). Funep, Jaboticabal, Brazil.

Morato R.G., Catão-Dias J.L. \& Arita G.M.M. 1993. Ocorrência de doença hemorrágica em Cervo-do-Pantanal (Blastocerus dichotomus). Anais do Congresso Brasileiro e I Encontro Internacional da Sociedade de Zoológicos do Brasil, Goiânia, Brazil.

Mota I.O., Castro R.S., Alencar S.P., Lobato Z.I.P., Lima Filho C.D.F., Araújo-Silva T.L., Dutra A.C.T. \& Nascimento S.A. 2011. Antibodies against bluetongue-virus group in goats and sheep from Pernambuco state and inferences on bluetongue epidemiology under tropical conditions. Arq. Bras. Med. Vet. Zootec. 63:1595-1598.

Murphy F.A., Gibbs E.P.J., Horzinek M.C. \& Studdert M.J. 1999. Veterinary Virology. 3rd ed. Academic Press, California. 344p.
Nogueira A.H.C., Pituco E.M., Stefano E., Curci V.C.L.M. \& Cardoso T.C. 2009. Detection of antibodies against the bluetongue virus in sheep in the region of Araçatuba, São paulo, Brazil. Ciênc. Anim. Bras. 10:1271-1276.

OIE 2016. World Animal Health Information System. <www.oie.int/ wahis_2/public/wahid.php/Diseaseinformation/WI/index/newlang/ en> Downloaded on 28 July 2016.

Orru G., Ferrando M.L., Meloni M., Liciardi M., Savini G. \& Santis P.D. 2006. Rapid detection and quantitation of bluetongue vírus (BTV) using molecular beacon fluorescent probe assay. J. Virol. Methods 137:34-42.

Osburn B.I. 2007. Bluetongue, p.455-459. In: Aitken I.D. (Ed.), Diseases of the Sheep. 4th ed. Blackwell Publishing, Oxford.

Pandolfi J.R.C. 1999. Língua azul e Doença Hemorrágica Epizoótica dos cervídeos: investigação sorológica em ruminantes domésticos e silvestres. Dissertação de Mestrado, Faculdade de Ciências Agrárias e Veterinárias, Jaboticabal, São Paulo, Brazil. 68p.

Pellegrin A.O., Sereno J.R.B., Leite R.C. \& Figueiredo H.C.P. 1997. Doenças da reprodução em bovinos no Pantanal: ocorrência de animais soropositivos para os vírus da rinotraqueíte infecciosa bovina, diarreia bovina e vírus da língua azul. Empraba Pantanal, Corumbá, 7:1-7.

Pinder L. \& Leeuwenberg F. 1997. Veado-catingueiro (Mazama gouazoubira Fisher, 1814). In: Duarte J.M.B. (Ed.), Biologia e Conservação dos Cervídeos Sul Americanos: Blastocerus, Ozotoceros e Mazama. Funep, Jaboticabal, Brazil.

Ribeiro-Silva A., Zhang H. \& Jeffrey S.S. 2007. RNA extraction from ten year old formalin-fixed paraffin-embedded breast câncer samples: a comparison of columm purification and magnetic bead-based technologies. BMC Molecular Biology 8, 118.

Shi S., Liu C., Perez J. \& Taylor C.R. 2005. Protein-embedding technique: a potential approach to standardization of immunohistochemistry for formalin-fixed, paraffin embedded tissue sections. J. Histochem. Cytochem. 53:1167-1170.

Shilton C.M., Smith D.A., Woods L.W., Crawshaw G.J. \& Lehmkuhl H.D. 2002. Adenoviral infection in captive moose (Alces alces) in Canada. J.Zoo Wildl. Med. 33:73-79.

Sorden S.D., Woods L.W. \& Lehmkuhl H.D. 2000. Fatal pulmonary edema in white tailed deer (Odocoileus virginianus) associated with adenovirus infection. J. Vet. Diagn. Invest. 12:378-380.

Souza T.S., Costa J.N., Martinez P.M., Costa Neto A.O. \& Pinheiro R.R. 2010. Antibodies against the bluetongue virus in sheep flocks of Bahia state, Brazil. Arqs Inst. Biológico, São Paulo, 77:419-427.

Stott J.L. 1999. Reoviridae, p.430-438. In: Hirsh D.C. \& Zee Y.C. (Eds), Veterinary Microbiology. Blackwell Science, Massachusetts.

Venditti L.L.R. 2009. Infecção pelo vírus da língua azul em ovinos e bovinos na região Sudeste do Brasil. Dissertação de Mestrado, Instituto Biológico, São Paulo, Brazil. 77p.

Williamson S., Woodger N. \& Darpel K. 2008. Differential diagnosis of bluetongue in cattle and sheep. In Practice 30:242-251.

Woods L.W., Hanley R.S., Chiu P.H., Lehmkuhl H.D., Nordhausen R.W., Stilian M.H. \& Swift P.K. 1999. Lesions and transmission of experimental adenovirus hemorrhagic disease in black-tailed deer fawns. Vet. Pathol. 36:100-110.

Woods L.W., Lehmkuhl H.D., Swift P.K., Chiu P.H., Hanley R.S., Nordhausen R.W., Stillian M.H. \& Drew M.L. 2001. Experimental adenovirus hemorrhagic disease in white-tailed deer fawns. J. Wildl. Dis. 37:153-158.

Woods L.W., Swift P.K., Barr B.C., Horzinek M.C., Nordhausen R.W., Stillian M.H., Parron J.F., Oliver M.N., Jones K.R. \& MacLachlan N.J. 1996. Systemic adenovirus infection associated with high mortality in mule deer (Odocoileus hemionus) in California. Vet. Pathol. 33:125-132. 